\title{
NPM1/ALK Fusion Protein
}

National Cancer Institute

\section{Source}

National Cancer Institute. NPM1/ALK Fusion Protein. NCI Thesaurus. Code C99362.

A fusion protein ( $680 \mathrm{aa}, \sim 75 \mathrm{kDa}$ ) that is encoded by the NPM1/ALK fusion gene. This protein contains the $\mathrm{N}$-terminal domain from the nucleophosmin protein and the cytoplasmic domain of the ALK tyrosine kinase receptor protein. 